\title{
STUDIES ON SOME ECOLOGICAL AND BIOLOGICAL OBSERVATIONS OF THE PARASITOIDS, Apanteles SPP. (HYMENOPTERA: BRACONIDAE) ON THE HAWAIIAN BEET WEBWORM, Hymenia recurvalis FAB.
} (LEPIDOPTERA: PYRALIDAE) AT FAYOUM DISTRICT Abd-Elgayed, A. A. ${ }^{1}$; S. H. A. Hussein ${ }^{2}$ and H. A. M. Saleh ${ }^{2}$ 1- Plant Protection Dept., Faculty of Agriculture, Fayoum University 2- Plant Protection Research Institute, Agric. Research Center, Giza

\begin{abstract}
The present work was carried out at Fayoum district to study ecological and biological observations on the parasitoids, Apanteles spp which associated with the Hawaiian beet webworm, Hymenia recurvalis Fab. during two seasons (2006/2007 and 2007/2008). Results showed that the parasitoids were recorded parasitizing on $2^{\text {nd }}$ instar larvae of this insect pest.

The Hawaiian beet webworm and its parasitoids, Apanteles spp. (Apanteles hymeniae Wilknson and $A$. marginiventris Creeson ) had one peak extended from first season until the end of December during the two successive seasons of study. Apanteles marginiventris was reared under laboratory conditions $\left(25 \pm 1^{\circ} \mathrm{C}\right.$ and $70 \pm$ $5 \%$ R.H.). Longevity of males and females averaged 3.90 and 6.30 days. Mean number of eggs laid was 15.10 eggs / female. Total duration of immature stages was $16.0 \pm 0.23$ days

Keywords: Hawaiian beet webworm, Hymenia recurvalis, Apanteles spp, biology and ecology
\end{abstract}

\section{INTRODUCTION}

Hawaiian beet webworm, Hymenia recurvalis Fab. is a major pest on spinach, Amaranthus spp. It also attacks many other crops and weeds. Larvae of $H$. recurvalis usually fed on exposed situations although they sometimes webbed or rolled leaves. Biological control is one of the important methods in an integrated control programs. Parasitoids are among the principal agents and limiting biotic factors affecting pest population densities. The Apanteles spp were more common than the other parasitoids larvae of H. recurvalis (Singh, 1960)

Peter and Balasubramanian (1984) showed that larvae of $H$. recurvalis and its parasitoids, Apanteles spp were collected from Amaranthus sp. from June to August in India.

In Egypt, this pest was recorded for first time in 2001 at El-Fayoum district on sugarbeet plantation (Hussein, 2001). On the other hand, ElGendi et al. (2003) and Hussein \& Abd El- Gayed (2008) reported that $H$. recurvalis is the most dangerous defoliators of sugarbeet plants, spinach and some weeds at El- Fayoum district.

However, scanty information has been paid to the seasonal abundance of $H$. recurvalis and their associated parasitoids and effect of certain climatic factors. Therfore, the present study was designed to study seasonal abundance of beet webworm and its parasitoids, effect of certain 
Abd-Elgayed, A. A. et al.

climatic factors on the populations of both insect pest and its parasitoids and some biological aspects of the parasitoid, A. marginiventris under laboratory conditions.

\section{MATERIALS AND METHODS}

\section{A. Stock culture:} 1-Insect pest:

Infested sugarbeet leaves with $H$. recurvalis larvae were collected from the field in El-Hadka village, El-Fayoum district) and kept in glass jars $(20 \mathrm{~cm}$ dia. $\times 30 \mathrm{~cm}$ ht.). The introduced leaves for these larvae were washed and dried carefully. The jars were covered with muslin and held in position by rubber bands. The jars were daily cleaned and fresh sugarbeet leaves were provided for larvae until pupation. The pupae were collected and placed in chimney glass cages until moths emergence. The emerged adults were seperated to female and male for mating. The eggs were incubatied until hatching and reached to $2^{\text {nd }}$ instar larvae (El-Gendi et al., 2006; Hussein \& Abd El- Gayed, 2008).

\section{2- The parasitoids, Apanteles spp:}

Cocoon of the parasitoids were collected from the field. The collected parasitoids were preserved in vials containing $70 \%$ ethanol and $5 \%$ glycerin, additional to prepared mounting slide specimens were used for identification. The parasitoids were identified to the species levels by the taxonomic keys according to Chou, (1979).

The newely emerged adults of Apanteles marginiventris were reared on $2^{\text {nd }}$ instar larvae of $H$. recurvalis in Petri dish $10 \mathrm{~cm}$., provided with dropetes of $10 \%$ sugar soluation and 10 changed daily hosts. These infeseted larvae were placed in clean Petri dishes containing of leaflet of sugarbeet (as host of larvae) and incubated under laboratory conditions until emergens of parasitoid adults.

\section{B. Ecological studies:}

Seasonal fluctuations of the main parasitoids ( $A$. marginiventris and $A$. hymeniae) and larvae of $H$. recurvalis were conducted at Fayoum district during two plantations of sugarbeet through two successive seasons, 2006/2007 and 2007/2008. The first plantation was cultivated in mid August, while the second plantation was cultivated in mid September. The samples (10 plants / 10 days intervals) were taken after twenty days from cultivation.

Specimens were placed in paper bags and transferred to the laboratory for inspection. The number of $H$. recurvalis larvae and the cocoons of the parasitoid, Apanteles spp. were recorded.

Temperatures $\left({ }^{\circ} \mathrm{C}\right)$ and relative humidity (\% R.H.) during the period of study were obtained from the Bulletin of Agricultural Meteorology, Ministry of Agriculture, Egypt for studying correlation between these climatic factors and the population of larvae of $H$. recurvalis and its associated parasitoids, Apanteles spp. 


\section{Biological aspects:}

The life cycle of the parasitoid, A. marginiventris was studied under laboratory conditions $\left(25 \pm 1^{\circ} \mathrm{C}\right.$ and $70 \pm 5 \%$ R.H. $)$. Ten couples of newely emerged adults were reared on $2^{\text {nd }}$ instar larvae of $H$. recurvalis. Each pair was kept in Petri dish $5 \mathrm{~cm}$., provided with dropetes of $10 \%$ sugar soluation and 5 larvae were changed daily. The pre- oviposition, oviposition, and postoviposition periods of adults and fecundity of females were recorded. Newly infested larvae of host were transferred individually in sterilized Petri dishes $(5 \mathrm{~cm})$ until transferred to pupae of the parasitoids. Twenty larvae were used as replicates. Observations were daily done to determine the duration of larval and pupal stages (Abd El-Gayed, 2004).

D- Statistical analysis:

The obtained data were statistically analyzed by simple correlation and regression for ecological studies and calculated the standard error for biological studies according to Senedecor and Cochran (1980).

\section{RESULTS AND DISCUSSION}

\section{1- Ecological studies:}

Survey studies indicated that two species of hymenopterous parasitoids (Apanteles hymeniae Wilknson and A. marginiventris Creeson) belong to family Braconidae. These results are in agreement with those obtained by Narayanan et al. (1957); Singh \& Parshad (1970); Boling \& Pitre (1970); Chaudhary \& Kapil, (1977); Kunnalaca \& Mueller (1979); Chou (1979); Peter \& Balasubramanian (1984) and Sourakov \& Mitchell (2008)in India.

The numbers of $H$. recurvalis larvae and its associated parasitoids, Apanteles spp on sugarbeet leaves from 2006 to 2008 are illustrated in Figures (1) and (2).

\section{First season 2006/2007:}

The obtained data on the population density of $H$. recurvalis larvae during 2006/07 season (first plantation) showed that the larvae were abundant throughout the months from September to December The highest number of larvae (40 larvae/10 plants) was recorded during the $4^{\text {th }}$ week of September, while the lowest one (2 larvae/10 plants) noticed during the $2^{\text {nd }}$ week of December. Fluctuations in the population density indicated that one activity period occurred during first plantation in, Figure (1).

Data illustrated in Figure (1) indicated that the parasitoids of $H$. recurvalis larvae during 2006/07 season (first plantation) were abundant throughout a period activity of the pest (from September to December). Fluctuations of population density showed one occurrence period, Fig (1). This period observed during the period from $2^{\text {nd }}$ week of September to the $4^{\text {th }}$ week of November, while its peak was noticed during the $2^{\text {nd }}$ week of October (19 parasitoids/10 plants).

Data of the $2^{\text {nd }}$ plantation showed that $H$. recurvalis larvae were abundant throughout the period extended from October to December during 2006/07 season (Figure 1). The highest number of $H$. recurvalis larvae. (22 
Abd-Elgayed, A. A. et al.

larvae/10 plants) were recorded during the $4^{\text {th }}$ week of October, while the lowest number ( 3 larvae/10 plants) were noticed during the $1^{\text {st }}$ week of December.
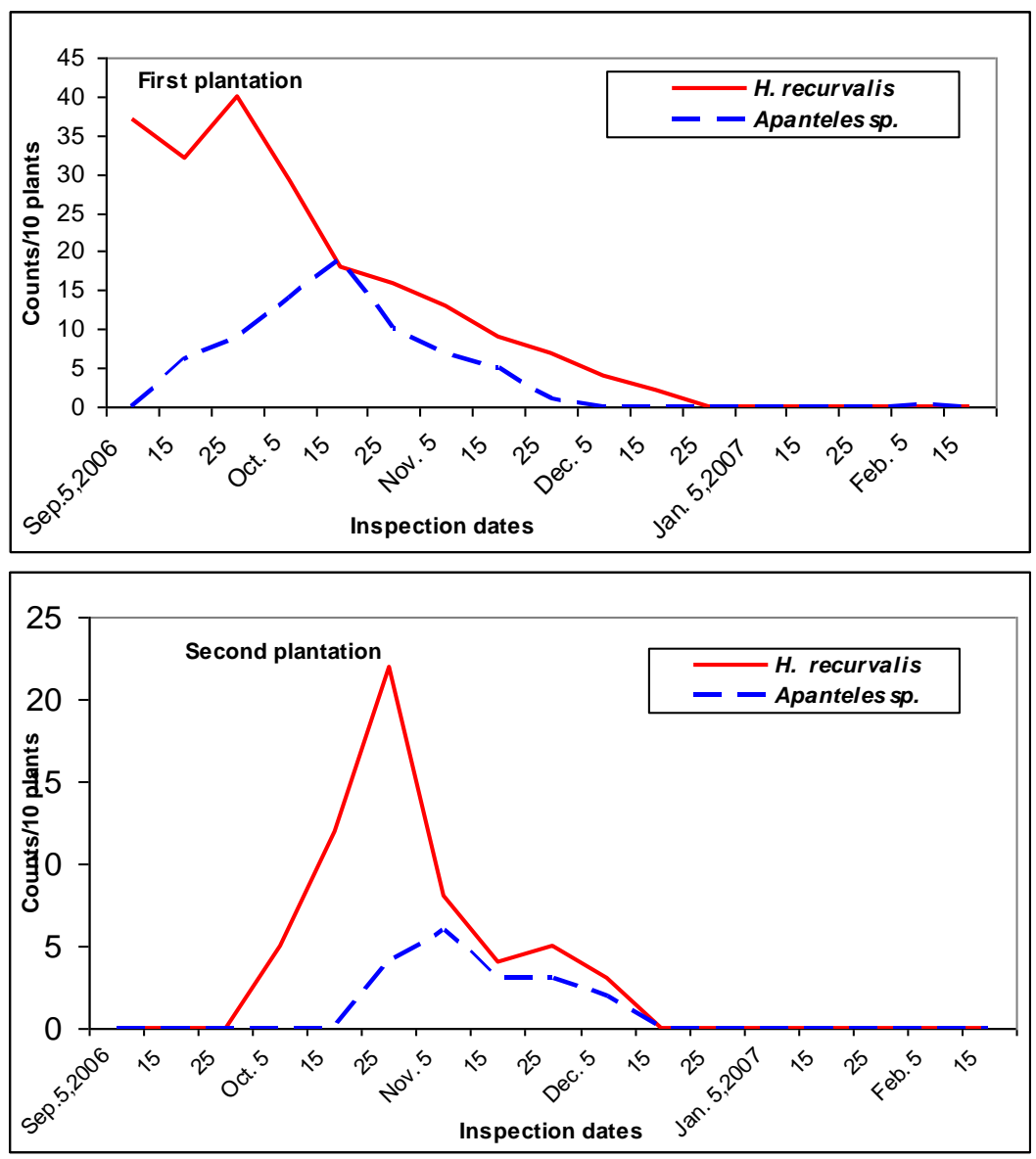

Fig. (1): Seasonal abundance of $H$. recurvalis and its associated parasitoids, Apanteles spp on sugarbeet during,2006/2007 season at Fayoum district.

Data presented in Fig (1) showed that $H$. recurvalis parasitoids during 2006/07 season (second plantation) were abundant from $4^{\text {th }}$ week of October to $1^{\text {st }}$ week of December, the fluctuations of population density detected one occurrence period was recorded.

Simple correlation between certain climatic factors and $H$. recurvalis parasitoids during the $1^{\text {st }}$ plantation showed a highly significant correlation with all activity periods. On the other hand, simple correlation was a significant with relative humidity. But, in the $2^{\text {nd }}$ plantation, simple correlation was insignificant with climatic factors. Simple correlation between certain 
climatic factors and population of $H$. recurvalis showed a highly significant correlation with min temperature, a significant with max. temperature and relative humidity, but insignificant with climatic factors in the $2^{\text {nd }}$ plantation (Table 1).

Table (1): Correlation coefficient between certain climatic factors and populations of $H$. recurvalis and Apanteles spp. on sugarbeet during 2006/2007 and 2007/2008 seasons at Fayoum district.

\begin{tabular}{|c|c|c|c|c|c|c|c|c|}
\hline \multirow[b]{2}{*}{ Climatic factors } & \multicolumn{4}{|c|}{$1^{\text {st }}$ plantation } & \multicolumn{4}{|c|}{$2^{\text {nd }}$ plantation } \\
\hline & $\mathbf{r}$ & $\begin{array}{l}\text { Slope } \\
\text { (b) }\end{array}$ & $\begin{array}{c}Y \\
\text { Int.(a) }\end{array}$ & $\begin{array}{l}P \text { and sign } \\
\text { of significant }\end{array}$ & $\mathbf{r}$ & $\begin{array}{c}\text { Slope } \\
\text { (b) }\end{array}$ & $\begin{array}{c}Y \\
\text { Int.(a) }\end{array}$ & $\begin{array}{c}P \text { and sign } \\
\text { of } \\
\text { significant }\end{array}$ \\
\hline \multicolumn{9}{|c|}{ H. recurvalis, 2006/2007 season } \\
\hline Min. Temp. & 0.581 & 1.822 & -13.57 & $0.0065^{\star \star}$ & 0.382 & 0.623 & -0.903 & 0.3980 \\
\hline Max. Temp. & 0.846 & 1.430 & -25.18 & $0.0162^{*}$ & 0.634 & 0.859 & -14.92 & 0.1264 \\
\hline Relative humidity & -0.640 & -1.322 & 87.97 & $0.0218^{*}$ & -0.728 & -0.934 & 60.86 & 0.0637 \\
\hline \multicolumn{9}{|c|}{ Apanteles spp. } \\
\hline Min. Temp. & 0.478 & 1.581 & -15.67 & $0.0014^{\star \star}$ & -0.326 & -0.171 & 5.129 & 0.4750 \\
\hline Max. Temp. & 0.515 & 1.300 & -27.33 & $0.0020^{\star \star}$ & -0.223 & -0.097 & 5.207 & 0.6304 \\
\hline Relative humidity & -0.660 & -1.001 & 64.69 & $0.0442^{*}$ & 0.230 & 0.094 & -2.728 & 0.6205 \\
\hline \multicolumn{9}{|c|}{ H. recurvalis, $2007 / 2008$ season } \\
\hline Min. Temp. & 0.902 & 1.577 & -7.847 & $0.0001^{\star *}$ & 0.826 & 1.711 & -10.49 & $0.0032^{\star *}$ \\
\hline Max. Temp. & 0.832 & 1.095 & -16.29 & $0.0004^{* *}$ & 0.844 & 1.268 & -21.27 & $0.0023^{\star *}$ \\
\hline Relative humidity & -0.542 & -1.845 & 119.10 & $0.0469^{*}$ & -0.542 & -1.933 & 123.26 & 0.1051 \\
\hline \multicolumn{9}{|c|}{ Apanteles spp } \\
\hline Min. Temp. & 0.228 & 1.634 & -12.61 & $0.0003^{\star \star}$ & 0.723 & 0.602 & -4.687 & $0.0182^{*}$ \\
\hline Max. Temp. & 0.350 & 1.225 & -23.74 & $0.0001^{\star \star}$ & 0.797 & 0.483 & -9.631 & $0.0057^{\star \star}$ \\
\hline Relative humidity & -0.168 & -2.041 & 126.38 & $0.0380^{*}$ & -0.608 & $\mid-0.872$ & 53.441 & 0.0621 \\
\hline
\end{tabular}

\section{Second season $2007 / 2008$ :}

As shown in figure (2), the populations of the parasitoid species took the same trend of season $2006 / 2007$, i.e., the parasitoid populations began to appear during the end of September until first December (after 20 days from appearance of the pest, $H$. recurvalis) and the population in first plantation higher than the second one.

The populations fluctuated to record one activity period. The peak (20 individuals $/ 10$ plants) was recorded in end of October (17.0 min. temp., 34.9 max. temp. and $56.7 \% \mathrm{RH}$ ) and decreased gradually until the first of December neither pest nor parasitoids were observed from mid December until end of plantation (end February).

The population of the parasitoids, $A$. marginiventris and $A$. hymeniae were lower than $1^{\text {st }}$ plantation and associated with activity period of $H$. recurvalis larvae. The peak (10 cocoons /10 plants) was recoded in the same activity period of first plantation in end of October (17.0 min. temp., 34.9 max. temp. and $56.7 \% \mathrm{RH}$ ) then decreased gradually until first of December Also no individuals were observed this period until end of plantation.

Generally, the relationship between the population of $H$. recurvalis larvae, associated parasitoids, Apanteles spp. and temperature were highly 
Abd-Elgayed, A. A. et al.

significant in the $1^{\text {st }}$ and $2^{\text {nd }}$ plantations. While the relationship between the population of the $H$. recurvalis \& its parasitoid and relative humidity were a significant, but in the $2^{\text {nd }}$ plantation were insignificant (table 1 ).
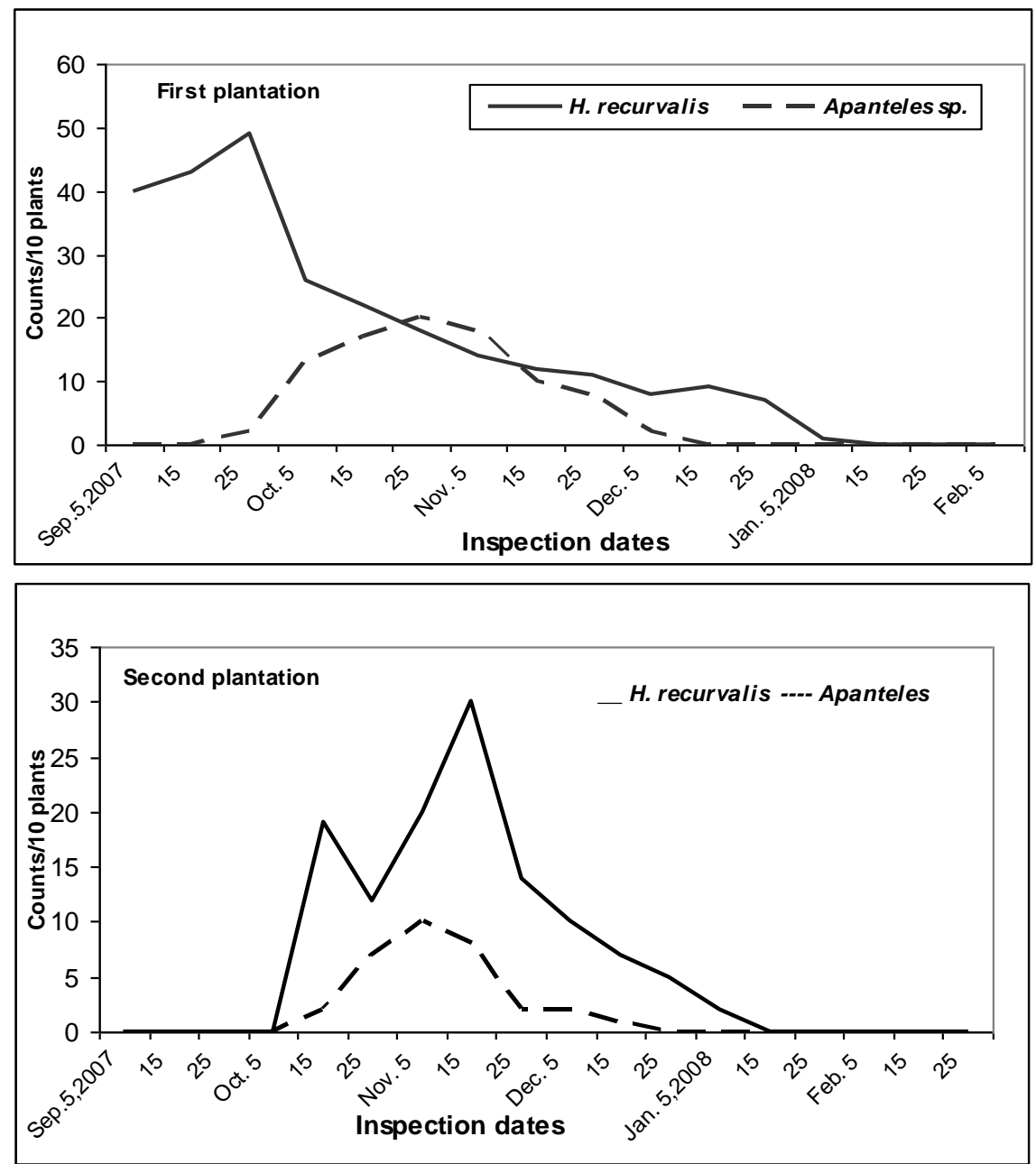

Fig. (2): Seasonal abundance of $H$. recurvalis and its associated parasitoids, Apanteles spp on sugarbeet during, 2007/2008 season at Fayoum district.

The above mentioned results are in agreement with those obtained by Narayanan et al. (1957); Boling \& Pitre (1970); Singh \& Parshad (1970); Chaudhary \& Kapil (1977) and Sourakov \& Mitchell (2008) in India they mentioned that the parasitoids, Apanteles spp were associated with $2^{\text {nd }}$ larvae of $H$. recurvalis during the period extended from July to September and no observed after November. 
In addition, in same region, Peter \& Balasubramanian (1984) found that larvae of $H$. recurvalis collected from Amaranths sp. from June to August and the percentage of parasitism by Apanteles spp. was the highest population $(11.0 \%)$ compared with other parasitoids.

\section{Biological aspects:}

\section{Durations of immature stages:}

Table (2) showed that the egg incubation period ranged between 2-4 days to recording the mean, $2.6 \pm 0.12$ days. The larval stage of the parasitoid, $A$. marginiventris has four instars. The total duration of larval stage lasted 8.3 days. Pre pupal stage had one day only in all replicates, while the pupation externally in white cocoon and the pupa ranged between 5-10 days. The mean total durations of immature stages was $16.0 \pm 0.23$ days. The longest period was 19.0 but the shortest one was 13.0 days. The sex ratio $\left(\delta^{\lambda}:\right.$ 은 were 1.7:1

Table (2): Hatchability, durations (in days) of the immature stages and sex ratio of $A$. marginiventris when, reared on $2^{\text {nd }}$ instar larvae of $\boldsymbol{H}$. recurvalis under laboratory conditions .

\begin{tabular}{|c|c|c|c|c|c|c|}
\hline Observation & $\begin{array}{c}\text { Incubation } \\
\text { Period }\end{array}$ & Larvae & Pre pupae & Pupae & Total & $\begin{array}{c}\text { Sex } \\
\text { ratio }\end{array}$ \\
\hline Mean & 2.6 & 8.3 & 1 & 7.5 & 16.0 & \multirow{2}{*}{$1.7: 1$} \\
\hline \pm S.E & 0.12 & 0.18 & 0.00 & 0.27 & 0.23 & \multirow{\gamma}{*}{$:+\frac{1}{10}$} \\
\hline Range & $2-4$ & $7-11$ & - & $5-10$ & $13-19$ & \\
\hline
\end{tabular}

Adult longevity:

Adult Stage:

Data in table (3) demonstrate that the pre-oviposition, oviposition and post-oviposition periods were $1.20 \pm 0.11,3.10 \pm 0.02$ and $1.20 \pm 0.10$ days, respectively. Female longevity was longer than that of male, as it was 6.30 for female and 3.90 days for male. The mean total deposited eggs / $q$ was $15.10 \pm 0.21$ eggs. The mean number of eggs /day/ $q$ was $3.7 \pm 0.12$.

Biological studies on the biology of this parasitoid species are rare or nil. In this respect, Singh \& Parshad (1970) in India, recorded this parasitoid as primary endoparasite on $2^{\text {nd }}$ instar larvae of $H$. recurvalis and found that the life cycle lasted 10-12 days, the adult lived 3-4 days and no eggs laid in November. Recently in the same region, Sourakov \& Mitchell (2008) reared the parasitoid, A. marginiventris on young larvae of $H$. recurvalis at $25^{\circ} \mathrm{C}$ and found that this parasitoid complete its development from egg to adult in 13.0 days and the cocoon took 7-10 days.

Table (3): Adult longevity (day) and fecundity of $A$. marginiventris when reared on $2^{\text {nd }}$ instar larvae of $\boldsymbol{H}$. recurvalis under laboratory condition.

\begin{tabular}{|c|c|c|c|c|c|c|}
\hline \multirow[b]{2}{*}{ Observation } & \multicolumn{3}{|c|}{ Oviposition periods / day } & \multirow[b]{2}{*}{$\begin{array}{c}\text { Female } \\
\text { longevity }\end{array}$} & \multirow[b]{2}{*}{$\begin{array}{c}\text { Male } \\
\text { longevity }\end{array}$} & \multirow[b]{2}{*}{$\begin{array}{l}\text { Number } \\
\text { of eggs }\end{array}$} \\
\hline & \begin{tabular}{|c|} 
Pre \\
oviposition
\end{tabular} & Oviposition & $\begin{array}{c}\text { Post } \\
\text { oviposition }\end{array}$ & & & \\
\hline Mean & 1.20 & 3.10 & 1.20 & 6.30 & 3.90 & 15.10 \\
\hline \pm S.E & 0.11 & 0.02 & 0.10 & 0.14 & 0.16 & 0.21 \\
\hline Range & $1-2$ & $3-4$ & $1-2$ & $2-8$ & $2-5$ & $5-19$ \\
\hline
\end{tabular}




\section{REFERENCES}

Abd-El-Gayed, A. A. (2008). Studies on effect of some pesticide residues on some pests attacking tomato and associated predators, Ph. D Thesis, Fac. Agric., Cairo Univ.,146 pp.

Boling J.C. and H. N. Pitre (1970). Life history of Apanteles marginiventris with description of immature stages. J. Kansas Entomol. Soc. 43: 465470.

Chaudhary, J. P. and R. P. Kapil, (1977). Record of a new host plant of Hymenia recurvalis Fab. and its parasites, Indian J. Entomol., 37(3) : 314.

Chou, L. Y. (1979): Notes on Apanteles (Hymenoptera: Braconidae) of Taiwan, J. Agric. Res. China, 28(4): 299-310.

El-Gendi, S. S.; Mostafa, F.F.M.; Ali, F.A. and Hussein, S.H.A. (2003). Survey of insect species associated with sugarbeet in Fayoum Governorate, Egypt and population dynamics of insect pests, Proc. $1^{\text {st }}$ Conf. Farm Integ. Pest Manag., Fac. Agric., Fayoum, 8-19.

El-Gendi, S. S.; Mostafa, F.F.M.; Ali, F.A. and Hussein, S.H.A. (2006). Certain biological aspects, threshold of development and thermal units for Hymenia recurvalis (Fab.),(Lepidoptera: Pyralidae), Arab Univ. J. Agric. Sci.,14(1): 447-456.

Hussein, S.H.A. (2001). Ecological studies on certain insect pests attacking sugarbeet crop in Fayoum Governorate, M. Sc. Fac. of Agric., ElFayoum, Branch Cairo Univ.,135pp.

Hussein, S. H. A. and Abd El- Gayed, A. A.(2008). Host preferences of the hawaiian beet webworm, Hymenia recurvalis Fab.(lepidoptera: pyralidae). Egypt J. Agric Res., 86(2): 531-540.

Kunnalaca, S. and A. J. Mueller (1979). A laboratory study of Apanteles marginiventris, a parasitoid of green clover worm, Environ. Entomol., 8: 365-368.

Peter, C. and Balasubramanian, R. (1984). New records of parasites of Hymenia recurvalis (Lepidoptera: Pyralidae) on Amaranthus, Entomon., 9 (1): 71:72.

Narayanan, E. S.; B. R. Subba Rao, and M. Ramachandra (1957). Hymenia recurvalis $F$. and its parasite complex, Plant Science, 46(4):241-246.

Senedecor, G.W. and Cochran, W. G.(1980). Statistical methods, $7^{\text {th }}$ Ed. 570 pp., lowa Stat., Univ. Press., Ames, lowa, USA.

Singh, S. R. (1960). The Hawaiian beet web-worm (Hymenia recurvalis F.), a serious pest of Indian spinach (Amaranthus viridis L.). Agric. J. Fiji, 30(1): 35-38.

Singh, S. R. and Parshad, B. (1970). Biological notes on (Cardiochiles hymeniae Fish \& Parshad), Indian J. Entomol., 32(2): 127-129.

Sourakov, A. and E. Mitchell, (2008). A wasp parasitoid, Cotesia marginiventris Cresson (Insecta: Hymenoptera: Braconidae), http: //creatures. ifas. ufl. edu. 
بعض الاراسـات البيئية والملاحظـات البيولوجيـة على طفيل الابنتيلس ( غشـائية

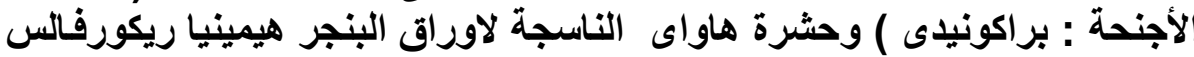

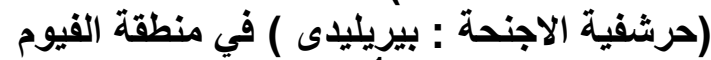

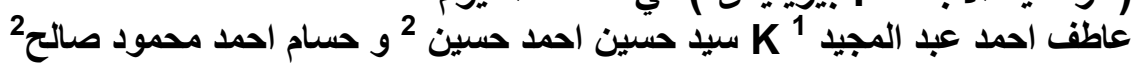

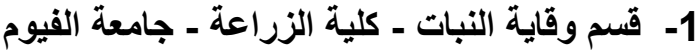
2- معه بحوث وقاية النباتات ـ مركز البحوث الزية الزراعية الفية

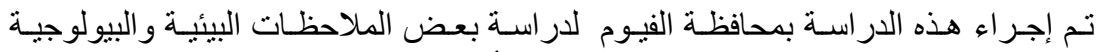

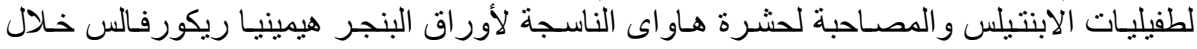

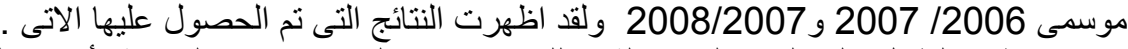

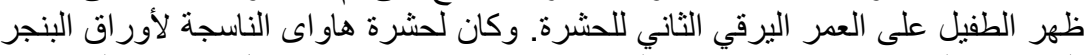

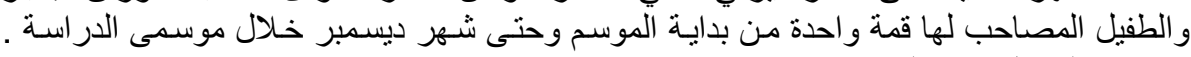

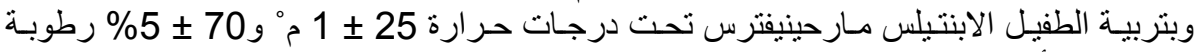

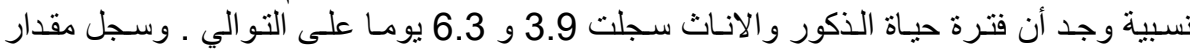

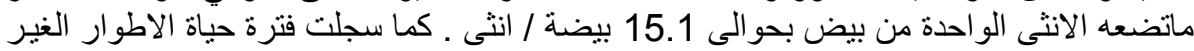

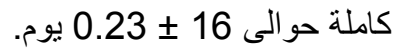

كلية الزراعة - جامعة المنصورة

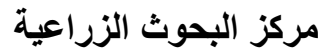

قام بتحكيم البحث عاد عاد أ. دام عادل حسن عبد السلام

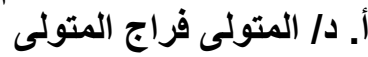

